\title{
COMPARATIVE ANALYSIS OF AN ADMINISTRATIVE APPEAL IN CROATIAN, SLOVENIAN, AND EU LAW
}

\author{
Ana Đanić Čeko, PhD, Assistant Professor \\ Josip Juraj Strossmayer University of Osijek, Faculty of Law \\ Stjepana Radića 13, Osijek, Croatia \\ adjanic@pravos.hr
}

\section{Polonca Kovač, PhD, Full Professor}

University of Ljubljana, Faculty of Public Administration

Gosarjeva ulica 5, Ljubljana, Slovenia

polonca.kovac@fu.uni-lj.si

\begin{abstract}
In administrative matters, parties enforce their rights and legal interests against obligations before the administrative authority of first instance; furthermore, they can file an appeal to the second instance if they deem decisions as illegal or as an injustice done. Exhaustion of the appeal is in most legal systems as well as according to Croatian (2009) and Slovenian (1999) General Administrative Procedure Acts $((G) A P A)$ as a procedural prerequisite to file further courts action, also in a situation of administrative silence with a negative act fiction. Besides said national GAPAs, the paper addresses draft EU Regulation (2016) as an EU APA too, in order to provide a comparative analysis of various acts. The right to good administration requires that administrative acts be taken by EU administration among others pursuant to timeliness and efficient legal protection. Based on normative national law analysis and case study focus of this paper is put on the administrative appeal, including through the lenses of an access to court. Paper provides an insight in Croatian, Slovenian, and EU APAs in prominent matter since it addresses constitutional and international principles of sound public governance. Authors establish that Croatian and Slovenian GAPAs provide an appropriate legal ground to achieve common European standards, yet they seem too detailed and fragmented in several dimensions; hence, EU APA can serve as a role model of their modernisation.
\end{abstract}

Keywords: administrative appeal, administrative procedural law, Croatia, Slovenia, EU, good administration 


\section{INTRODUCTION}

Appeal against authoritative decisions presents the key legal means of questioning lawfulness in addition to being one of the most frequently used instruments of public protection of the citizens. The right to an appeal is an integral element of basic human and citizens' rights while representing one of the main institutes in protection of human rights. The appeal is, in almost all legal proceedings, perceived as fundamental and comprehensive legal remedy. Along with the proscribed limitations, the right to file an appeal against the decisions of the first instance administrative authorities is present in most of the European countries and it usually poses a rule in the comparative law.

As a regular legal remedy, in the Republic of Croatia and the Republic of Slovenia, the aapeal was riesed to the rank of constitutional guarantee in both constitutions from 1991, and then at the same time elaborated legally withinnumerous administrative fields, yet mostly directly by national GAPAs (ZUP) from 2009 and 1999, respectively. Based on the fact that Croatia and Slovenia have a similar geo-political position and historical backround as parts of Austria and former Yugoslavia, their respective laws regrading administrative procedure and related Administrative Dispute Acts (ADA) are very similar despite the fact that the Croatian GAPA was enforced a decade after the Slovenian one. ${ }^{1}$ The significance of the appeal and its purpose in the administrative process law are particularly evident within the regular processes of legal protection of the citizens while handling administrative matters by public law authorities. This clearly refers to administrative procedures in which the appeal regulation is very widely positioned. It is, therefore, extremely important to approach the matter of forming and elaborating the legal remedy systems with caution and consideration in order to ensure the quality of the functioning of competent authorities while at the same time contributing to respecting the legitimacy and equality and preserving the lawfulness and legal security. The more developed the legal systems are, the more legal means there are for the legal subjects to protect their legal authorisations (subjective rights) in the case they have been disrespected by the state or any other authority.

See Zakon o općem upravnom postupku (Official Gazette of the Republic of Croatia No. 47/09), and Zakon o splošnem upravnem postopku (ZUP, Official Gazette of the Republic of Slovenia No. $80 / 99$ and amendments). Moreover, Croatia and Slovenia have rather comparable regulation of judicial review regarding individual administrative acts via administrative dispute before special courts; see Zakon o upravnim sporovima (Official Gazette of the Republic of Croatia No. 20/10, 143/12, 152/14, 94/16, 29/17), and Zakon o upravnem sporu (ZUS-1, Offcial Gazette of the Republic of Slovenia No. 105/06 and amendments). See also Koprić, I., Administrative Procedures on the Territory of Former Yugoslavia, Brussels, OECD, SIGMA, 2005, pp. 1-4, [http://www.sigmaweb.org/publications/36366473. pdf], accessed 25. March 2020 
An effective remedy is one of the fundamental principles of European administrative procedural law and European administrative procedures, that is, a general principle which should govern EU administration. The right to effective remedy is a key component to a legal system under the rule of law. As far as the right to effective remedy is concerned; this notion is to be understood in a broader sense, namely as administrative or judicial way to protect or challenge a disputable administrative act. As seen in the CJEU case law, ${ }^{2}$ it is necessary to focus on the "effectiveness" of legal remedy, namely legal (judicial, but also administrative) protection, which not only offers a more or less pro forma defence, but actually protects the party in a given legal situation, which is often not the case if the appeal is non-devolutive or non-suspensive and/or is handled for an unreasonably long period of time. In such regard, Art. 13 of the ECHR explicitly underline the effectiveness of legal remedy already at the level of national authorities.

Since many European countries have procedural rules under which they act in administrative matters, this is not a rule at EU level. Member States are required to adapt national legislation and to apply EU law adequately and uniformly, which entails knowledge, application and interpretation of material and procedural law provisions. The lack of codified rules of procedure found in the various sources of EU law and the sectoral nature of European administrative procedural law affects unequal treatment, fragmentation, unsystematic, incoherence, etc.

On the EU level, the first attempt to design supranational general procedural regulations was the European Code of Good Administrative Behavior, adopted by the EU Ombudsman in 2001 and revised in 2004 and 2012. A further formal landmark in the direction of an APA for the EU was the European Parliament Resolution of 2013 with recommendations to the Commission on a Law of Administrative Procedure of the EU and further Resolution of 2016, including draft Regulation for an Open, Efficient and Independent European Union Administration. $^{3}$

2 See Galetta, D.-U. et al. The General Principles of EU Administrative Procedural Law, Brussels, European Parliament, 2015, pp. 18: "The right is enshrined in Art. 47 of the Charter, in Art. 6 \& 13 ECHR and recognised as a general principle of EU law is a key component to a legal system under the rule of law. According to this principle, neither the EU nor MS can render virtually impossible or excessively difficult the exercise of rights conferred by EU law, are obliged to guarantee real \& effective judicial protection (C14/83) and are barred from applying any rule or applying any procedure which might prevent, even temporarily, EU rules from having full force \& effect (C-213/89)., [https://www.europarl.europa.eu/RegData/etudes/ IDAN/2015/519224/IPOL_IDA\%282015\%29519224_EN.pdf], accessed 25. March 2020

3 European Parliament Resolution of 15 January 2013 with Recommendations to the Commission on a Law of Administrative Procedure of the European Union (2012/2024(INL)) and Resolution of 9 June 2016 for an Open, Efficient and Independent European Union Administration (2016/2610(RSP)) with Proposal for Regulation of the EP and of the Council. Available in all official EU languages at [http://www. 
The aim of this paper is to point out the compliance of the Croatian and Slovenian GAPA solutions with the EU APA Proposal in relation to legal remedies and legal protection in the administrative procedure. The main research questions are therefore two. Firstly, we analyse what are the main similarities and differences of the Croatian, Slovenia, and EU (G)APAs on administrative appeal. Secondly, we evaluate, which of respective regulations seems the most efficient in terms of good administration and sound public governance principles. ${ }^{4}$ The necessity of the principle of the two instances in administrative procedure (as a rule) is also being discussed, whereby emphasizing the principle of efficacy and the duration of the administrative procedure. The authors are, therefore, through normative analysis and comparative methods describing the procedure regarding the appeal in Croatian and Slovenian administrative procedure while specifying specific exceptions to constitutional and legal rights to an appeal. The right to an appeal is a constitutional guarantee, fundamental human, conventional and legal right, which can exceptionally be excluded, that is, regulated by special laws which then do not allow an appeal against the decision of the first instance authority to be made. Moreover, the appeal is a suspensive legal remedy, which means that it postpones the legal effects. With regard to that, on the basis of normative analysis of special laws, certain examples of special administrative areas have been emphasized, where the appeal does not postpone the execution of the decision reached by the first instance administrative authority. In this part of the paper, there is also a short overview of the influence and implications of the European administrative procedural law on national administrative procedures, that is norming of the national administrative procedure in particular, under the influence of the processes of Europeanization,

europarl.europa.eu/sides/getDoc.do?type=TA\&reference=P7-TA-2013-0004\&language=EN\#top $]$ and [http://www.europarl.europa.eu/sides/getDoc.do?pubRef=-//EP//TEXT+TA+P8-TA-2016-0279+0+$\mathrm{DOC}+\mathrm{XML}+\mathrm{V0} / / \mathrm{EN}]$, accessed 25. March 2020. See specifically the formal and social grounds for its adoption

4 About these concepts see more in Venice Commission, Stocktaking on the Notion of Good Governance and Good Administration. Study 470/2008, 2011, pp. 1-30,[https://www.venice.coe.int/webforms/documents/?pdf=CDL-AD(2011)009-e], accessed 25. March 2020; Hofmann, H. C. H.; Schneider, J.-P.; Ziller, J. The ReNEUAL Model Rules, 2014, [http://www.reneual.eu/images/Home/ ReNEUAL-Model_Rules-Compilation_BooksI_VI_2014-09-03.pdf], accessed 25. March 2020; Auby, J.-B., Codification of Administrative Procedure, Brussels, Bruylant, 2014; Koprić, I.; Kovač, P. (eds.), European Administrative Space: Spreading Standards, Building Capacities, Bratislava, NISPAcee, 2017, [http://www.nispa.org/files/publications/proceedings/NISPAcee-Proceedings-2016-Zagreb. pdf], accessed 25. March 2020; Koprić, I. et al., Legal Remedies in Administrative Procedures in Western Balkans, Danilovgrad, ReSPA, 2016; Kovač, P., The requirements and limits of the codification of administrative procedures in Slovenia according to European trends, Review of central and east European law, vol. 41, no. 3/4, 2016, pp. 427-461; Kovač, P., Principles of administrative procedure in selected CEE countries: between national legacies and European trends, Public Administration in a Democratic Society: Thirty Years of Democratic Transition in Europe, International Conference, Dubrovnik, Croatia, 3-6 October 2019. [https://iju.hr/ipsa/2019/papers/ip19p2.pdf], accessed 25. March 2020 
harmonisation and coordination with the acquis communautaire. The issues of national legal traditions of the member states in this particular administrative area, which is specific and on EU level and national process autonomy have also been emphasized. In the end, the authors provide conclusions, establishing that Slovenian and Croatian GAPAs are compliant to EU standards, both generally and as regards legal remedies regulation, yet there are further possibilities in both national laws to strive for more concise, principles based and hence efficient codification within the good administration context.

\section{ON THE IMPACT OF EU PROCEDURAL LAW ON THE REGULATION OF CROATIAN AND SLOVENIAN ADMINISTRATIVE PROCEDURE}

\subsection{The Europeanization and the position of National Administrative Procedures in relation to the existence of European Administrative Procedural Law}

Different directions of influences and "pressures" lead to remodelling of the administrative law by abandoning traditional concepts. Emphasis is, in the process, put on administrative and judicial capacities necessary for adequate transposition of the European law and its effect on national legislation. ${ }^{5}$ National administrations find themselves in complex situations in which they need to balance between various influences since they are simultaneously exposed to streams demanding redefining of their administrative traditions. Ruffert highlights that despite the importance of national traditions, the term is rather vague which influences the relationship of national traditions towards common principles. ${ }^{6}$ In accordance with that, it is necessary to be aware of the attempts of creating an area in which standards and principles are to be followed and applied with the aim of achieving efficacy of national administrative systems and complete legal protection of its citizens.

Đanić, A.; Lachner, V., Utjecaj pojave globaliziranog upravnog prava na nacionalne upravne sustave s naglaskom na hrvatsko upravno postupovno pravo, in: Belaj, V. (ed.), Conference proceedings 2nd international conference Public administration development, Vukovar, Croatia, 11-12May, 2012, pp. 163-179

6 See more Ruffert, M., Common Principles and National Traditions: Which Perspective for European Administrative Legal Scholarship?, in: Ruffert, M. (ed.), Administrative Law in Europe: Between Common Principles and National Traditions, Europa Law Publishing, Groningen, 2013, pp. 215. About national traditions see more Schmidt-Aßmann, E., Administrative Law in Europe: between Common Principles and National Traditions, in: Ruffert, M. (ed.), Administrative Law in Europe: Between Common Principles and National Traditions, Europe Law Publishing, Groningen, 2013, pp. 34-35 
When discussing the EU administrative law, ${ }^{7}$ implementation ${ }^{8}$ and application of EU rights through cooperation between the institutions and the EU bodies and national level are implied. The European influence on national administrative law is closely related with the concept of shared government. ${ }^{9}$ Many European proceedings are regulated by various administrative areas (market competition, government supports, environment protection, medication sales, technology, food safety etc.). In these instances, roles are being mixed and cooperation between the EU institutions and national administrations is being realised as a part of procedural frameworks in horizontal and vertical dimensions. National bodies can be facing a dilemma whether domestic or/and EU law should be applied in particular cases considering there are different rules and practice. ${ }^{10}$ If the EU law does not contain any specific provision, it is for the national legal order of each Member State to establish procedural rules for actions intended to safeguard the rights of individuals, in accordance with the principle of procedural autonomy. ${ }^{11}$ The only restriction to the national procedural autonomy is that in each case, the application of national procedural law in the absence of EU procedural rules has to meet two conditions: principle of non-discrimination or equivalence and the principle of effectiveness. ${ }^{12}$

The application of the mentioned principles regarding the administrative procedure is considered as duty in order for the EU law to be applied effectively with its full effectiveness ensured (effectiveness (process equality) and effective legal protection (Effet utile)). Even after having been enlisted in the national law, the norms of the EU law are still applicable and can be called upon in every national judicial

About the evolution of European Administrative Law see more Schwarze, J., European Administrative Law, Sweet and Maxwell, Luxembourg, 1992, p. 1433-145

8 Schwarzedraws a distinction between direct and indirect administrative implementation of European law, emphasizing that administrative procedure in indirect administration lacks uniformity due to the principle of procedural autonomy. See Schwarze, J., Judicial Review of European Administrative Procedure, Law and Contemporary Problems, vol. 68, no. 1, 2004, pp. 86

9 Widdershoven, R., European Administrative Law, in: Seerden, J. G. H. R. (ed.), Administrative Law of the European Union, its Member States and the United States, A Comparative Analysis (third edition), Intersentia, Ius Commune Europaeum, Book 109, 2012, pp. 245-246

10 The only request for a preliminary ruling from the High Administrative Court of the Republic of Croatia lodged on 8 February 2018-Hrvatska banka za obnovu i razvitak (HBOR) v Povjerenik za informiranje Republike Hrvatske, Case C-90/18, ECLI:EU:C:2018:685. See more on Decision of the Court from 6 September 2018,[http://curia.europa.eu/juris/document/document.jsftext=\&docid $=205742 \&$ pageIndex=0\&doclang=HR\&mode $=1$ st $\&$ dir $=\& o c c=$ first $\&$ part $=1 \& c i d=1947276 \#$ Foot note*], accessed 29. March 2020

11 SeeCaseC3/16, Aquino v. BelgischeStaat, ECLI:EU:C:2017:209; CaseC161/15, BensadaBenallal v Étatbelge, EU:C:2016:175; CaseC74/14, Eturas and Others v Lietuvos Respublikoskonkurencijostaryba, EU:C:2016:42

12 Verhoeven, M., The Costanzo Obligation, Intersentia, Ius Commune Europaeum, Book 93 2011, p. 49 
and administrative proceeding. Regardless the national procedural autonomy, the demands for equality and effectiveness has led to considerate European strivings and has influenced national administrative systems and procedures.

The solution lies in codification of fundamental process rules applicable in every country, which is the result of convergence of the administrative procedural law. EU has established that in some areas it is important to set the minimum of standards to satisfy and apply the common procedural demands. Supporting that is also the removal of different proceedings which negatively affect the functioning of the unique market. Conclusively, it is to be emphasized that the Europeanization process has had influence on changing the Croatian and Slovenian GAPA, which will shortly be presented in the paper.

\subsection{Influence of draft EU APA on Croatian GAPA}

When the Republic of Croatia became a member of the European Union, the process was based on transposition and adequate implementation of acquis communautaire. On the way to "opening the European door" numerous challenges were set regarding the demands under the influence of the European administrative procedural law. The European administrative procedural law, within which the European administrative procedure was established, has a great influence on application of general administrative procedure. Modernisation of administrative proceedings in Croatian law was also greatly influenced by the Directive 2006/123/ EC of the European Parliament and of the Council of 12 December 2006 on services in the internal market(hereinafter: Directive). ${ }^{13}$ The implication which the Directive has on the procedural law refers to demands for administrative simplification, establishing both cooperation and points of single contact. The regulation of a single administrative place ${ }^{14}$ has been reduced to only one legal article and the institute does sadly not function in practice, as it should referring to content and organisation. ${ }^{15}$ Some of the attempts have been reduced on functioning for the business sector (how to start and establish a business; how to start an entrepreneurial initiative) within the framework of the Financial Agency and Croatian

13 Directive 2006/123/EC of the European Parliament and of the Council of 12 December 2006 on services in the internal market, OJ L 376, 27.12.2006, p. 36-68, [https://eur-lex.europa.eu/legal-content/ EN/TXT/?uri=celex\%3A32006L0123], accessed 14. March 2020

14 Art. 22 of.the GAPA

15 See more Đanić Čeko, A., Has the Implementation of the One-Stop-Shop (Point of Single Contact) enabled simplification of the Croatian Administrative Procedure to increase the efficiency of Public Administration?, in: Cingula, M.; Rhein, D.; Machrafi, M. (eds.), 31st International Scientific Conference on Economic and Social Development -"Legal Challenges of Modern World", Split, 2018, pp. 580-588, [http:// www.esd-conference.com/past-conferences], accessed 24. March 2020 
Chamber of Economy (START system). ${ }^{16}$ The Point of Single Contact has been established through the framework for the free market, which is horizontally regulated under the Croatian Services Act. ${ }^{17}$ Croatian public administration has to make numerous improvements in this area following the examples set by Austria, Hungary, Slovenia, and Germany. The emphasis is put on the system for providing electronic services by using the e-citizens system. ${ }^{18}$ The number of e- services is constantly growing within the e-citizens system, which is definitely a positive thing causing the simplification of the administrative procedure and enabling prompt communication with citizens and public sector.

Furthermore, the demands have been set for providing and easily accessing information, ensuring remote procedures and formalities by electronic services. The Directive has introduced and formalised certain procedural solutions in the Croatian administrative procedure, which are incorporated within the principles, electronic communication provisions, and legal protection expansion both against the proceedings or missing the proceedings by public-legal bodies and public services providers. The important step has been made by legally norming the institute of legal contract, which has not been specified in the draft EU APA. Regarding this, new regular legal remedy, the appeal, has been introduced and the number of extraordinary legal remedies has been lowered from seven to three, which has been more than necessary. The Croatian legislator has modernised the system of legal protection in accordance with the European standards. ${ }^{19}$ There is, however, the issue of two instance administrative authority. Regarding the jurisdiction of the second instance authority in the appeal, one should emphasise the legislator's intention to avoid the repetition of the procedure by providing the authority to solve the issue based on the merits. The principle of legal hearing ${ }^{20}$ of the party as one of the fundamental procedural parties' rights has not encountered its place among the principles of the administrative procedure, as was the case with the old GAPA. ${ }^{21}$ When referring to its principles, the Croatian administrative procedure could be enriched with more European principles following the example of the draft EU APA. More attention should be focused on achieving the content reali-

16 [http://psc.hr/en/point-of-single-contact/], accessed 28. March 2020

17 See Art. 6 of the Croatian Services Act, Official Gazette No. 80/11

18 [https://pretinac.gov.hr/KorisnickiPretinac/eGradani.html], accessed 28. March 2020

19 Đanić, A.; Lachner, V., Modernizacija sustava pravne zaštite gradana s naglaskom na upravne reforme, in: Katalinić, B. (ed.), Proceedings/2nd International Conference "Vallis Aurea"-focus on: Regional Development, 2010, pp. 0281-0289

20 See Art 14 of the EU APA

21 General Administrative Procedure Act, Official Gazette No. 53/91, 103/96. The party's right to be heard, although not among the principles of administrative procedure, found its place in Art. 30 of the GAPA (party statements, declaration of the parties) 
sation of the right to good government, which simultaneously contains the right regarding formalism and too detailed regulation. When it comes to discussing the ways in which administrative procedure can be initiated, the possibility to submit an application or notification to the citizens due to public interest protection as one of the constitutional rights of every citizen. One of the goals of the Strategy for the development of public administration (2015-2020)22 refers to the administrative system reform in accordance with the best practice and experiences of good governance according to the European standards. Is the Croatian GAPA, therefore, a traditional law and is it valid to claim that EU APA is a modern European codification? Regarding the fact that the Republic of Croatia was obligated to harmonise its legislation with the EU laws and conduct a comprehensive reform of the public administration and administrative adjudication. There is always room for improvement, which should be set as one of the priorities, primarily to enhance and simplify the system of administrative proceedings and decision-making, better communication and cooperation with citizens and business sector as well as more quality in providing public services.

\subsection{Influence of draft EU APA on Slovenian GAPA}

In Europe, especially Central Europe, the emphasis of (G)APAsis predominantly on the codification of single-case administrative decision-making, aimed at protecting the public interest under substantive law while also, and in particular, protecting the rights of the parties. Dual regulation on general and specific procedures is characteristic for Slovenia as in the most other CEE countries. However, sector specific fields are often regulated differently from the GAPA, so that the normative procedural status under leges speciales is often more problematic as it may be under the GAPA. ${ }^{23}$ Moreover, it is characteristic for Slovenia that the mutatis mutandis application of the GAPA is pursued by Art. 4, i.e. fundamental principles' (like the right to be heard, the right to obtain a reasoned decision and to file legal remedies)

22 [https://www.sabor.hr/hr/prijedlog-strategije-razvoja-javne-uprave-za-razdoblje-od-2015-do-2020godine], accessed 26. March 2020

23 Examples for Slovenia in Avbelj, M, Komentar Ustave RS [Commentary to the Constitution], Nova Gorica, New University, 2019. (comments to Art. 22, 23, 25). For example, sector-specific laws partially extend ordinary serving or abbreviated fact-finding procedure, contrary to the general solutions under the GAPA. Similarly in Croatia (See Koprić, I.; Đulabić, V. (eds.), Modernizacija općeg upravnog postupka i javne uprave u Hrvatskoj [Modernisation of Administrative Procedure and Administration in Croatia], Institute for Public Administration, Zagreb, 2009) where, despite constitutionally equal protection of rights, entire special administrative procedures are introduced by over 60 laws. However, one needs to consider which rules belong to the general and which ones to sectoral procedural law; any new rules, typical of or necessary for a particular field, belong only to the latter (Kovač, op. cit, note 4). For instance, the one-stop-shop system (in Slovenian: VEM) is one of Slovenia's reform successes, awarded by the UN and integrated into the more comprehensive Slovenian Business Point (SPOT). 
application in non-administrative yet still public law matters where the procedure is not regulated by sectoral laws. Thus, even after two decades, this provision means that unlike other national APAs, there is no need to extend the scope of the GAPA to other administrative acts.

Hence, GAPA's and sectoral legislation amendments in Slovenia have been relatively minor compared to the changes in most European countries over the last decades. ${ }^{24}$ We assume this being an expression of conservatism and established tradition in GAPA use; that is in Slovenia similarly to the Croatian and other CEE countries' social and legal systems. Additionally, one can observe rather detailed codification of Slovenian GAPA. While the number of provisions per se is not necessarily an indication of obsolescence, we need to understand that comparisons show $5 \%$ to one half of the Slovenian volume, which is a problem since users cannot distinguish between more important and rather operational rules and norms. ${ }^{25}$

Nevertheless, under the influence of globalisation and EU guidelines, also the Slovenian GAPA from 1999, and even more the procedural regulation in sector-specific laws, such as on the field of entrepreneurs' actions (referring to Directive2006/123/EC), has been revised in several GAPA's amendment. These changes have been directed towards of simplification and red tape reduction (e.g. possibility of waiving an appeal to achieve instant enforceability in 2008), introducing joint procedures (e.g. joining up visas for living and working in Slovenia), deregulations, digitalisation, et simile. Thus, for example, institutions such as a one-stopshop or positive fiction in case of administrative silence in the area of entrepreneurship and social benefits; or alternative dispute resolution in inspections, tax collection, etc. are defined in sectoral laws although not found in the GAPA (as in Croatia). Hereby, an analysis of changes over time in Slovenian GAPA shows that politics and specific economic interests have often taken priority over professional arguments and comparative good practices. ${ }^{26}$

24 This applies not only to several Western countries, e.g. through changes towards greater efficiency and participation in Germany or the Netherlands, or through the adoption of a completely new codification in France in 2015, but also to CEE and the Western Balkans, where nearly all the countries revised their APAs under the influence of SIGMA. Koprić, et al., op. cit., note 4; Kovač, op. cit., note 4

25 Report on the following number of articles in national GAPAs: US (1946) has 16 articles, Sweden (1986) 33, Finland (2003) 71, Austria (1991) and Germany (1976) just over 100 articles, Croatian APA (2009) 171 articles. Slovenia (1999) with 325 articles. See Koprić; Đulabić, op. cit., note 23

26 Already the adoption of the Slovenian GAPA in 1999, as an almost uncritically filtered and rather only editorially revised codification of the Yugoslav law of 1956, suggests that the then politicians lacked the courage or the ability to modernize the law in the sense of a break with socialism and related social phenomena. On the other hand, one of the reasons for continuity is probably a considerable degree of modernity of the Yugoslav APA, so no major reforms were required, albeit one can emphasize at least rather detailed formalization of the codification 
Regarding fundamental principles as well legal remedies, Slovenian GAPA has reduced their number since 1999. Instead of 13 principles as before, the Slovenian GAPA comprises nine principles; however, these are classical principles, not modern ones such as good administration. ${ }^{27}$ The same applies to the number of legal remedies: there are currently six, although European trends suggest that for the sake of legal certainty, their number should be lower yet still guaranteeing a balance between protection of the public interest and protection of the rights of the parties.

\subsection{Conclusions on the joint EU APA and MS autonomy}

In sum, if one compares the characteristics of the Croatian and Slovenian GAPAs to the EU level in terms of modern principles and innovative aspects, there are still many options ahead of us, like introducing alternative dispute resolution and more collaborative relations. Particularly, regarding legal remedies, we can observe that national codifications in question still pursue many remedies and even an appeal is rather formally prescribed, inter alia as an obligatory step before access to courts despite often excessive length of proceedings in both countries, especially Croatia. Neither balance nor consistency in legal remedies' regulation is ideal in both national laws, as seen through various comparative studies. ${ }^{28}$

When compared to the EU level, in order to achieve systematically adjusted and standardised administrative proceedings, it is considered that there should be a general procedural law proscribing the minimum of fundamental principles and standards of the proceedings which are mutual for all the systems. ${ }^{29}$ Administrative procedure demands a common regulation within the European administration as well as reassignment of tasks within the executive integration. The same European procedural law would not be directly applied in national administrations since most of the countries have their own regulations regarding the administrative procedure, however, its influence would be evident in every aspect of the activities led by European law (this has already been achieved in numerous sectors such as market competition, public procurement, right to asylum, environment protection etc.).

\footnotetext{
27 More in detail see Kovač, (2019) op. cit., note 4, Venice Commisssion (2011), Galetta, et al., op. cit., note 4

28 For instance, see Koprić et al., op. cit., note 4; Kovač 2019, op. cit., note 4; Cf. Aubyet al., op. cit., note 4

29 See also Đerđa, D., Upravni postupci u europskom pravu, Hrvatska pravna revija, vol. IX, no. 4, 2009, pp. 62; Franchini, C., European Principles Governing National Administrative Proceedings, Law and Contemporary Problems, vol. 68, no. 1, 2004, pp. 196
} 
In EU, most important are Art. 6 and 13 of the European Convention on Human Right on ensuring a fair trial and the right to an effective remedy, respectively, and Art. $41^{30}$ in conjunction with Art. 42 and 47 of the EU Charter on the rights to the fair administration of procedures (2009). These principles are binding on all administrative authorities, while the regulation of procedural law is left to the discretion of the Member States even though draft EU APA will be adopted. The procedural autonomy of the Member States has been pursued specifically by the case law of the CJEU, as developed over time. At first, such autonomy was seen as unlimited, but recently the CJEU has acknowledged the main common principles in several cases. ${ }^{31}$ However, despite the acknowledgment of the procedural autonomy and national peculiarities of the EU Member States, it is important to emphasize that the so-called 'import-export' convergence based on the EU principles of equivalence and effectiveness has been overcome. Also important in such regard is the creation of a common identity or the relevant legal culture by spilling over to the national level. ${ }^{32}$

Therefore although the EP Resolutions and the ReNEUAL Model Rules explicitly stress that such codification will apply only to EU authorities and not to Member States, we expect that the principles and rules - when adopted - will be transposed to the national level as well. This is further supported by the de minimis rule, whereby general provisions, despite the regulation being lex generalis, at least in terms of fundamental standards, represent a minimum standard to which a special regulation would be only very exceptionally subordinate. One should, however, bear in mind that it is dangerous to assume equal or similar principles of public procedures will be applied in every member state and its administration. Uniformity might be illusory, because, although there might be a rule which is "the same" for a certain number of countries, it might not be interpreted equally, or applied equally. A certain compromise solution can be found in the creation of codifica-

$30 \quad, .$. In the title of article 41 it was clearly expressed that it is a right, but the interpretation of the article 52 para. 2-4 of the Charter leads to the conclusion that the rights ensured by the Charter were interpreted from the Treaties, European Convention on Human Rights or common constitutional traditions of the EU Member States. The problem is that the right to good administration was ensured by the constitutional norms only in Finland..." See more Siuciński, R., Convergence of Law-Examples from European Administrative Procedure, Vilnius, 2013, pp. 305-306, [http://www.tf.vu.lt/dokumentai/naujienos/Renginiai/tarptautine_studentu_konferencija_2013.pdf], accessed 17. March 2020

31 With regard to cases referred tothe CJEU, see Case C-453/00, Kühne \& Heitz NV v. Produktschap voor Pluimvee en Eieren, ECLI:EU:C:2004:17; Case C-234/04, Rosmarie Kapferer v. Schlank \& Schick GmbH, ECLI:EU:C:2006:178; Case C-507/08, EC v. Slovakia, ECLI:EU:C:2010:802; Case C-603/10, Pelati d.o.o. v. Slovenia, ECLI:EU:C:2012:639

32 With regard to the spill-over effect, see Hofmann; Schneider; Ziller, op. cit., note 4; Kovač, op. cit., note 4 
tion of European administrative procedural rules, especially in areas where there are significant differences between national rules for implementation of EU law.

\section{ADMINISTRATIVE APPEAL IN THE CROATIAN AND SLOVENIAN GAPAS}

\subsection{Analysis of Croatian GAPA on an appeal}

One of the aims of administrative procedures is legitimate proceedings and dealing with administrative matters as well as reaching legitimate and righteous decisions within proscribed deadlines. It is, therefore, necessary to ensure adequate and systematic mechanisms of hierarchy control which would eliminate possible mistakes in proceedings of the public law authorities. As a key legal means of questioning lawfulness and one of the most frequently used instruments of public protection of the citizens, an appeal, is accordingly emphasized. Along with certain proscribed limitations, the right for filing an appeal against the decisions of the first instance public law authorities in the administrative procedure is found in most of the European countries and it usually presents the rule in the comparative law.

The guarantee of the right to appeal against individual legal acts made in first-instance proceedings by authorised bodies is contained in the Art. 18(1) of the Constitution of the Republic of Croatia. ${ }^{33}$ As an exception, appeal may be denied in cases specified by law if other forms of legal protection are ensured. Therefore, the basic conditions for the exclusion of the appeal against administrative acts of the first instance public law authorities are set in the Art. 18(2)of the Constitution of the Republic of Croatia. Specific conditions and rules of derogation from the right to appeal in administrative procedure are regulated in the Art. 3(1) of the GAPA. Only individual issues of administrative procedure may be regulated otherwise by a special law, when this is necessary for proceeding in individual administrative areas, and if this is not in violation of the basic provisions and the purpose of this GAPA.

Right to appeal is one of the fundamental principles of any legal protection proceeding, and thus the administrative. Legal protection of parties to administrative proceedings through an appeal is also regulated within one of the basic principles of administrative procedure, the principle of a party's eight to legal remedy. As a general rule, in administrative matters parties firstly need to enforce their rights before the administrative authority of first instance, furthermore they can file an

33 Official Gazette No. 56/90, 135/97, 113/00, 28/01, 76/10, 5/14 
appeal to the second instance. Appeal procedure is intermediate stage before access to court. Interested parties are required to follow a preliminary administrative procedure. This preliminary procedure has two objectives: extended decision-making and legal protection. Administrative appeal may only complement judicial legal protection by establishing an opportunity of self-review to be optionally and mandatorily passed through before a court action. ${ }^{34}$ This self-review is only effective if it is taken seriously by the administrative authorities. So, we can conclude that exhaustion of the appeal is in most legal systems procedural prerequisite to file court action. Mandatory administrative appeal is regulated in Germany, Netherlands, ${ }^{35}$ Belgium, Spain, Denmark etc, while optional one in France and Italy.

According to Croatian GAPA (IV part) from 2010 there are two regular (ordinary) legal remedies in administrative procedure as a mechanism of legal protection: 1) appeal (Art. 105-121) ${ }^{36}$ and 2) objection (Art. 122). In administrative procedure party has always the right to appeal against a first instance body decision and in the cases of the so called "administrative silence" when first instance body did not made its decision in the law defined deadline. ${ }^{37}$ Only specific laws may provide that in specific administrative matters an appeal is not allowed, provided that the protection of rights and lawfulness is ensured in some other way.

First of all, appeal is regular, universal, devolutionary, bilateral and suspensive legal remedy. ${ }^{38} \mathrm{An}$ appeal, almost inevitably, postpones the legal effects of the decisions until the solution to an appeal is delivered to the party (unless proscribed differently by the law). It can be, however, exceptionally decided, for the reasons prescribed by law (Art. 112(3)), that the appeal does not possess a suspensive effect. ${ }^{39}$

34 See Stelkens, U., Administrative Appeals in Germany, in: Dragos, D. C.; Neamtu, B. (eds.), Alternative Dispute Resolution in European Administrative Law, Springer, 2014, pp. 3-55

35 For example see the system in Netherlands Barkhuysen, T.; Ouden den, W.; Schuurman, Y.E., The Law on Administrative Procedures in the Netherlands, NALL 2012, april-juni, pp. 6-7, [https://openaccess.leidenuniv.nl/bitstream/handle/1887/19406/NALL-D-12-00004.Law\%20on\%20admp.pdf?sequence $=2]$, accessed 22. March 2020

36 About reform of the system of legal remedies in the administrative procedure see Đerđa, D., Reforma sustava pravnih lijekova prema novom Zakonu o općem upravnom postupku, in: Koprić, I.; Đulabić, V. (eds.), Modernizacija općeg upravnog postupka i javne uprave u Hrvatskoj, Suvremena javna uprava, Zagreb, 2009, pp. 162-169

37 If a party applies for a certificate (a fact for which official records are kept) and the public body refuses to issue a certificate to it or does not issue it within 15 days, an appeal may be lodged

38 Dragos distinguishes types of appeal: 1) hierarchical appeal or recourse and 2) so-called quasi-hierarchical appeal, external appeal, or sometimes recours de tutelle. See Dragos, C.D., Administrative Appeal, In: Farazmand, A. (ed.) Global Encyclopaedia of Public Administration, Public Policy and Governance, Springer, Chma, 2016, pp. 1-2

39 Some examples of specific laws that provide for the regulation of the non-suspensory nature of an appeal are: GAPA (Art. 36 (2), Temporary Alimony Act (Art. 20 (3)), Social Welfare Act (Art. 100 a (4), 
Specificity related to suspensive effects of legal remedies refers to the protection of their applicant from the execution of the effects of the refuted decision. It is, therefore, possible that the applicant might act this way in order to stall the proceedings and while doing so not respecting the proscribed procedural discipline.

Furthermore, when it comes to ensuring adequate and efficient legal protection during an appeal in the administrative procedure, it is definitely important to mention the principle of effectiveness and decision-making within a reasonable deadline, as well as process guarantees such as the right for an effective legal remedy and right for accessing (an independent and unbiased) court. The issues regarding the length of the procedure when solving administrative matters and reaching a decision based on merits are closely connected to the issue regarding the necessity of the two instance administrative decision-making authorities in the appeal. In scientific circles, dilemmas about the necessity of the presence of the administrative decision-making of the second instance, that is, the exclusion of the appeal from the administrative procedure, have been frequently emphasized. The parties have, in the process, the possibility to initiate an administrative dispute by filing a lawsuit against the decision of the appeal to a competent first instance administrative court. The decision-making and handling the legal matters are, typically, conducted in two instances in the administrative procedure and two instances in administrative adjudication (four instances). Another possibility is the three instance model (decision of the second instance authority - administrative procedure + lawsuit + appeal - administrative dispute) when the decision is reached by the competent ministry or any other competent second instance authority against which an appeal is not permitted, but an administrative dispute can still be initiated as well as the possibility for an appeal against the decision of the administrative court (if permitted)..$^{40}$ There are, however, certain exceptions in specific special administrative areas. The exception when the party is allowed, after receiving the decision of the administrative procedure, to acquire administrative - judicial protection from the High Administrative Court of the Republic of Croatia in one instance administrative dispute (the two instance model). ${ }^{41}$ The

Art. 114 (5)), Law on Building Inspection (Art. 50 (2)), Law on Customs Service (Art. 75 (7)), Law on Civil Servants (Art. 80 a), et simile

40 For example Art. 38(3), Art. 39(5) Act on International and Temporary Protection, Official Gazette No. 70/15, 127/17, Art. 12(5), Art. 15(6), Art. 18(2), Art. 29(12) Forest Act, Official Gazette No. 68/18, 115/18, 98/19, Art. 46(3) Law on Foreigners, Official Gazette No. 130/11, 74/1369/17, 46/18

41 Đanić Čeko, A., Žalba u upravnom sporu u hrvatskom i poredbenom pravu, Pravni fakultet Sveučilišta u Zagrebu, Zagreb, 2016, doctoral thesis, p. 278-328.; Đanić Čeko, A., Specifičnosti uloge Visokog upravnog suda Republike Hrvatske u jednostupanjskom upravnom sporu na osnovi posebnih zakona (lex specialis),Harmonius Journal of Legal and Social Studies in Southand East Europe, vol. VII, 2018, pp. $17-45$ 
example of such specific administrative - judicial protection is prescribed by the Art. 39(4), Art. 51(4), Art. 67-69 of the Competition Act. ${ }^{42}$

A comparative example of excluding the right to an appeal in the administrative procedure is set by Austrian GAPA, ${ }^{43}$ in which one instance administrative procedure has been introduced (with certain exceptions). Moreover, in the French administrative law, the parties have the possibility to choose, it is therefore not necessary to follow the regular rules of appeal in order to initiate the administrative dispute. When the law allows it, the appeal in administrative procedure (recours administratif préalable) can be a mandatory prerequisite for initiating an administrative dispute. ${ }^{44}$ Supporting this, we point out that Dragos mentions two major systems of administrative appeals - mandatory and optional. ${ }^{45}$ One might conclude that the system of appeal in the administrative procedure is a rule in most of the countries while at the same time providing the example of administrative tradition, one from which it is difficult to detach or even completely abandon. Regardless the propositions of normative solutions about the possibilities for filing an appeal in administrative dispute, it is only in specific, legally proscribed cases, where it is possible to overburden the administrative adjudication.

Conclusively, it is to be stated, that the appeal in administrative procedure is to be enforced in accordance with the fundamental legal standards which need to be objectively applied and interpreted by the second instance public law authorities in order to achieve adequate balance between the ambition for effectiveness and legal protection of the rights and legal interest of the parties. Moreover, it is necessary to harmonise and standardise, which is currently still a large number of special laws, regarding the deviations from the GAPA in relation to proscribing the appeal deadlines (shortening the deadline) or unclear defining of the deadlines, failing to define the appeal authority, exceptions from effects of the appeal and exclusion of the appeal in specific administrative areas. Special emphasis is to be put on the important jurisdiction of the decisions based on merits reached by the second instance authorities in the administrative appeal (to independently deal with the entire administrative matter), so without nullifying the first instance decisions

42 Official Gazette No. 79/09, 80/13

43 IV. Teil: Rechtsschutz, Berufung (\$ 63-67) Allgemeines Verwaltungsverfahrensgesetz 1991-AVG, StF: BGBI. Nr. 51/91 (WV)with an amendmentBGBI. I Nr. 58/18, [https:/www.ris.bka.gv.at/GeltendeFassung.wxe? Abfrage=Bundesnormen \&Gesetzesnummer $=10005768 \&$ FassungVom $=1992-12-31$ ], accessed 20. March 2020

44 Gjidara, M; Britvić Vetma B., Francusko-hrvatski pojmovnik, Split/Paris, 2016, p. 96

45 Dragos, op. cit. note 38, pp. 2 
and reinitiating the procedure. ${ }^{46}$ By applying the authority to reach the decisions based on merits, there are no prolongations of the administrative procedure and no contributions to creating the so-called "ping-pong" effect. It is acted in accordance with the principle of effectiveness and faster realisation of rights. Everything mentioned should be systematically questioned and discussed about with the aim of unburdening the system of administrative procedure from ineffectiveness, too long duration of the procedure, overly exaggerated formalism in some particular procedures, comprehensive legal protection and establishing of the system of efficient control over regulation and application of means of legal protection.

\subsection{Analysis of Slovenian GAPA rules on the appeal}

A legal remedy in the Slovenian administrative appeal system is a specific procedural action that initiates, before the competent body, the procedure to review and establish the compliance of a specific administrative act with an abstract legal norm. Pursuant to Articles 25, 157, and 158 of the Slovenian Constitution, the legal remedies provided by law (the GAPA or a sector-specific law), the administrative appeal and court remedies are the only way to modify, annul ab initio, or annul an administrative act. The appeal is the only legal remedy applied prior to the act becoming final, even though the Slovenian GAPA recognises a further five extraordinary legal remedies. The right to administrative appeal is provided for by Art.13, which operationalises the constitutional and international right to an effective remedy. Thus, the effectiveness of legal remedies is part of the principle of the rule of law (Art. 2 of the Slovenian Constitution) and is directly related to equality before the law, the protection of personality and human dignity, the equal protection of rights, the right to judicial protection, legality, an administrative dispute, and finality (res iudicata). The constitutional arrangement allows an exception, namely the exclusion of appeals based on a sound reason, which is aimed at distinguishing a specific administrative area from the general rule. Especially the non-suspensiveness of a legal remedy is incompatible with the requirement of the effectiveness of a remedy, as derived from the provisions of the Constitutional Court in cases U-I-297/95 and U-I- 339/98. The exclusion of the suspensory effect of an appeal must be reasonably grounded otherwise it implies a violation of the equal protection of parties' rights (Art. 22 of the Slovenian Constitution). ${ }^{47}$

\footnotetext{
46 Art. 117(1) and Art. 119(3).The adoption of a new decision by the incomplete resolution of the first instance body should only be necessary. Therefore, reference to the nature of an administrative matter which is not defined should be avoided, but evaluated on a case-by-case basis by the appeal body $\left(2^{\text {nd }}\right.$ instance administrative body/authority)

47 As analyzed in detail by Avbelj, op. cit, note 23 and Kovač, 2016 and 2019, op. cit, note 4. More also about empirical data in Dragos, Neamtu, op. cit., note 4
} 
In Slovenia, an administrative appeal is a mandatory (i.e. before court action can be taken), always devolutionary, and in principle suspensory remedy. The GAPA furthermore lists seven procedural errors (errores in procedendo) which are considered to be severe violations infringing upon formal legality. ${ }^{48}$. An appeal may be filed pursuant to the GAPA (Art. 222 and 256) also if the administrative body fails to act, i.e. if the act concerning the party's request has not been issued within the prescribed time limit. ${ }^{49}$ Based on the GAPA and ADA, the legal path in asserting administrative rights and interests in Slovenia comprises the following stages:

- Administrative proceedings, initiated upon request from one of the parties or ex officio in order to protect public interest;

- Administrative appeal proceedings, conducted usually by the line ministry and at the initiative of a party, within 15 days from the notification of the administrative act; afterwards the decision is complete and enforceable;

- Further, a court action may be initiated within 30 days from the notification of the decision in administrative appeal by any party or by a government representative to protect public interest; there is a further option of an appeal to Supreme Court; upon court decision, the matter becomes final;

- Should the administrative authority or the court in deciding on the constitutional rights or obligations of the party violate such rights, the party may also file a constitutional appeal before the Constitutional Court; if the court denies the appeal, party may invoke the protection based on European Convention.

In the Slovenian legal order, the appeal thus has a fourfold purpose. Firstly, due to its dispositive nature and devolutionary and suspensory effects, the appeal is an instrument of protection for the rights of the parties. Secondly, since the right of appeal is also guaranteed to representatives of the public interest (i.e. the state attorney), the appeal also protects legality. Pursuant to the GAPA, the reformatio in peius for the appellant is restricted, as it applies only in the event of reasons justifying certain extraordinary legal remedies or in the event of the most severe violations. The appeal body ex officio examines only violations of substantive law

48 Art. 237(2). These can be classed into three groups: (1) issues relating to unlawfulness (illegality) linked to the administrative body (jurisdiction, the impartiality of officials), (2) issues relating to the party (legal interest, proper representation, the right to be heard, communication in an official language), and (3) issues relating to the administrative act as a prescribed form (such as the fact that it must be in writing and contain the prescribed elements)

49 According to the ADA (Article 28/3), in force since 2007, also a failure to act in an appeal procedure may constitute grounds for an appeal in an administrative dispute or even a special appeal if within three years from the start of the administrative procedure a decision on the merits has not been concluded (referring to the right to a decision within a reasonable time). This prevents a 'yo-yo effect' 
and significant procedural errors (Art. 247). Thirdly, particularly with the appeal body's power to assess ex officio absolute and significant procedural errors and the misapplication of substantive law, the appeal aims at the coherence of the administrative system in a specific field and at the equality of the parties. However, in Slovenia, an appeal is never optional; therefore, an appeal is also a measure to reduce courts' workload.

Pursuant to the GAPA, the appeal is the only regular legal remedy in Slovenia with a devolutionary nature ${ }^{50}$ and belongs to the group of hierarchical appeals (recours hiérarchique, widerspruch). These elements include the admissibility and the devolutionary and suspensory effects of the appeal. The appeal is a basic GAPA principle for all administrative matters but can be excluded by law since from the viewpoint of constitutionality the appeal is not necessary if the law provides a different possibility to challenge an administrative act, particularly when administrative act making is not aimed at uniformity of legal practice. In such case, direct judicial review (court action) is an admissible alternative to the administrative appeal. In this context, the Constitutional Court has already developed constitutionally acceptable exceptions as to when an appeal in administrative proceedings can be fully excluded. In addition to the need for speed in decision making in order to ensure early completeness and enforceability for the protection of public interest or the rights of the parties, or when the body deciding at first instance is an otherwise appeal body.

Given the constitutionally provided responsibility of ministers and ministries for the state of affairs in their respective areas of work, the appeal body according to the GAPA and nearly all sector-specific laws as well as the body supervising the powers of local government is otherwise the line ministry. According to the GAPA, for most parties the purpose of (effective) appeal is in delaying the execution. The suspensory effect is given in principle de iure (Art. 236) to all administrative appeals in order to temporary delay the execution of the administrative act as a consequence of the administrative appeal to avoid irreparable damage resulting from the execution of the contested administrative act if the decision is to be amended afterwards as illegal. Exceptions are possible directly pursuant to the GAPA and ADA in individual cases if public interest could be jeopardised or if the field law provides otherwise.

50 There are also some cases of what is known as de facto non-devolution (or quasi-hierarchical or improper appeal), owing to the internal organization, vertical and centralized decision making of the competent authorities like municipalities or social insurance institutes, and personal links because of poor staffing capacities (e.g. in municipalities); thus, the appeal is naturally losing its efficiency More in Dragos, op. cit, note 4 
As a rule, an appeal is filed to the body of first instance within 15 days from the serving of the administrative act. The body of first instance is obliged to examine the appeal (whether it is allowed and filed in due time and by an entitled person) and, if it establishes that the appellant is right, the possibility of issuing a new administrative act (Art. 240-243). If the appeal is formally suitable, it must be within 15 days from receipt sent to the appeal body to examine the justification of appeal in terms of subject matter. If the appeal is justified, the appeal body issues within two months a new administrative act whereby it declares the first administrative act null or ex tunc replaces the contested administrative act, or annuls the contested administrative act $a b$ initio and remands the case to the body of first instance for renewed proceedings with the deadline of an additional month (Art. 251).In order for an appeal to be effective, the appeal body must decide in two months at the latest, or a court action can be filed pursuant to the ADA (negative fiction). In practice, some appeal bodies take a very long time to decide, mainly on the social field. With the serving of the appeal administrative act dismissing, rejecting or granting the appeal, the administrative act becomes complete; the parties have 30 days at maximum to file a court action.

To sum up, the regulation of the (internal) administrative appeal in Slovenia by the Constitution, the GAPA, and the ADA is rather traditional and pursues primarily legality. Such regulation is still (over)detailed and lacks the stimulating elements of a modern participative and consensual definition of administrative relations.

\section{COMPARISON OF CROATIAN AND SLOVENIAN GAPA VS.DRAFTEU APA ON THE RIGHT TO ADMINISTRATIVE APPEAL}

\subsection{Croatian vs. Draft EU APA}

Since administrative process is no longer only a part of the national law, it is being developed as a core of administrative procedural law of the EU. It is therefore crucial to be familiarized with the European administrative procedural rules. Klučka claims that precisely that manner of development of this aspect of law is not "a one-way street", but it, however, offers the possibility for every legal system of the member states to be transferred along with their own traditions and principles into the European administrative law. ${ }^{51}$ In a well-organized administrative structure one of the most important values is adequate and reliable application of such

51 Klučka, J., The General Trends of EU Administrative Law, The International Lawyer, vol. 41, no. 4, 2007, pp. 1048 
rules. ${ }^{52}$ The EU law is implemented in national courts, but also in other bodies of public authorities including administrative authorities. ${ }^{53} \mathrm{~A}$ member state needs to harmonise its process norms to enable the protection of subjective rights based on the EU right, while at the same time not proscribing the form of the national procedural law. ${ }^{54} \mathrm{EU}$ law and national administrative law are increasingly intertwined and they are tied closely together forming a coherent whole. Because of this, they are sometimes referred to as an integrated or composite order. ${ }^{55}$

On the European level, large number of proceeding are related to sectoral administrative procedures. Only a few areas of the Union's administrative activities are subject to a systematic approach and there are many gaps and uncertainties. The absence of standardisation across sectors and the general variety of EU administrative law procedure allows a deeply variegated system to which the access of the ignorant public is restricted. ${ }^{56}$ The first step toward efficient administrative decision-making processes of the European administration is to ensure consistent EU administrative procedures systematically (formal codification) in one legal

52 The first GAPA was regulated in 1889 in Spain and in Austria 1925, standardization of which affected the European-continental system of administrative law (Germany-1976, Italy-1990, Hungary-1957, Poland-1960). Rusch, W., Administrative Procedures in EU Member States, OECD/SIGMA, „Conference on Public Administration Reform and European Integration-Budva, Montenegro“, 2009, pp. 6-8

53 This obligation was incorporated into the Constitution of the Republic of Croatia (OG No. 56 / 90, $135 / 97,8 / 98,113 / 00,124 / 00,28 / 01,41 / 01,55 / 01,76 / 10,85 / 10,05 / 14)$, and is regulated by Art. 145 (4). It follows from this constitutional provision that administrative bodies are obliged, as well as the courts, to apply a European law which has priority and is superior to national law, that is, not to apply national law if it is contrary or the provisions of national law are duplicated / coincide with European. This obligation was established in Case C-103/88 Fratelli Constanzo S.p.A. v Commune di Milano, (1989) ECR 1839, $\$ \$ 30$ and 31 of the judgment. More about Constanzo obligation see in: Livioara Goga, G., The Obligation of the National Administrative Organs to Reexamine their own Decisions in the Context of the Recent Jurisprudence of the Court of Justice of the European Union, Acta Universitatis Danubius Juridica, vol. 16, no. 3, 2010, pp. 162-169, [http://journals.univ-danubius.ro/index. $\mathrm{php} /$ juridica/article/view/677/634], accessed 15. March 2020. The same applies to the obligation to adopt an interpretation which makes the national standard harmonized with the European one

54 See more Ćapeta, T.; Rodin, S., Osnove prava Europske unije na temelju Lisabonskog ugovora, Narodne novine, Zagreb, 2011, p. 143-153. The position of EU administrations in relation to the legal system as a whole and the interaction between EU law and national law amplius Borchardt, K.-D., The ABC of European Union Law, Publications Office of the European Union, Luxembourg, 2010, p. 113-123

55 Prechal, S.; Widdershoven, R.J. G.M.; Jans, J.H., Introduction, in: Prechal, S.; Widdershoven, R.J. G.M.; Jans, J.H., (eds.), Europeanization of Public Law (second edition), Europa Law Publishing, Groningen, 2015, pp. 7-9.

56 Cărăuşan M., Towards an Administrative Procedure of the European Union: Issues and Prospects, Acta Universitatis Danubius, vol. 8, no. 2, 2016, pp. 89, [https://www.researchgate.net/publication/331089750_Towards_an_Administrative_Procedure_of_the_European_Union_Issues_and_ Prospects], accessed 17. March 2020 
text (common procedural framework). ${ }^{57}$ Adequate system of administrative procedures, well-developed administrative procedures is imperative. Proposal for a regulation of the EU APA from 2016presentstheunificationoftheproceduralrulesreferring to administrative activities of the EU administration. These procedural rules aim at assuring both an open, efficient and independent administration and a proper enforcement of the right to good administration. ${ }^{58}$

We would say it is a type of a general procedural law (lex generalis) since it does not question other legal EU acts regulating special administrative procedural rules. It is only used to complete such legal acts, while being interpreted in accordance with its relevant provisions. In addition, in order to ensure adequate and further development of the established procedural rights ${ }^{59}$ and obligations, while guaranteeing content application on good administration (Art. 41). ${ }^{60}$ Supporting this is an excerpt from the Preamble of the Regulation proposition: „Properly structured and consistent administrative procedures support both an efficient administration and a proper enforcement of the right to good administration guaranteed as a general principle of Union law and under Article 41 of the Charter ${ }^{\text {"61 }}$ Considering there are many institutions and EU bodies that form the Union administration, in numerous administrative areas the number of administrative proceedings and decisions is being increased. It is therefore necessary to ensure adequate protection of procedural rights of the EU citizens. Hence, the application of the EU APA is obligatory when by handling an administrative matter the EU law is being applied (EU administrative activities).

The analysis of Section 4 Art. 20 of the EU APA (Conclusion of the Administrative Procedure) with respect to the remedies, provisions will be presented as it follows. The chosen procedural institutes and relevant provisions from the both

57 See more Đerda, D., Towards the Codification of the EU Administrative Procedural Law, in: Koevski, G. (ed.) EU Administrative Law and its Impact on the Process of Public Administration Reform and Integration into the European Administrative Space of South East European Countries, Skopje, Macedonia: Centre for SEELS, 2014, pp.79-83; ĐanićČeko, A.;Petrašević, T., Procedural Rights of the Parties in Croatian and European Administrative Procedure-lack of one common Administrative Procedure? Is Regulation on Administrative Procedure necessary in the EU?, Draft paper, International Conference: "Public Administration in a Democratic Society:Thirty Years of Democratic Transition in Europe", 3-6 October 2019, Dubrovnik, Croatia, Ipsa Conference 2019, pp. 1-19, [https://iju.hr/ipsa/2019/papers/ ip19p27.pdf], accessed 22. March 2020; Đerđa, D., Jerčinović, A., Upravni postupak u pravu Europske unije: kodifikacijski izazov, Zbornik radova Pravnog fakulteta u Splitu, vol. 57, no. 1, 2020, pp. 88-97

58 Point 14 of the Preamble of the EU APA. See also Art 1 (2) of the EU APA

59 The procedural rights of parties are contained in the Art. 8 of the EU APA

60 Charter of Fundamental Rights of the European Union (2016/C 202/02), Official Journal of the European Union, C 202/389, 2016, p. 13, [https:/eur-lex.europa.eu/legal-content/HR/TXT/PDF/?uri=CELEX:12016P/TXT\&from=FR], accessed 23. March 2020

61 Point 12 of the Preamble of the EU APA 
legal sources are shown in the table. ${ }^{62}$ In order to simplify the realisation of rights to an effective legal remedy, the Union administration should in legal acts clearly state the legal remedies available to parties. Apart from the possibility to initiate a court procedure or file an appeal to the European Ombudsman, ${ }^{63}$ the party should have the right to ask for an administrative questioning, along with receiving notification regarding the procedure and the time limit available for filing such a request. According to Art. 20 of the EU APA, parties are allowed to an administrative review of the administrative acts. The procedure of the irregularities oversight refers to the administrative acts which have an unfavourable effect on their rights and legal interests. Furthermore, it is pointed out that the request is to be submitted to a hierarchically higher authority, in case there is no such authority, then to the authority who has reached the act. The parts that need to be contained in an administrative act are proscribed, as well as a three-month time limit in which it is necessary to reach a legal act, whereby respecting the timeliness in handling administrative matters. Supporting that, the introductory part of the Section 30 of the Preamble of the Regulation proposition proscribes, that in case of overstepping the allowed time limit when reaching an administrative act, the party in the administrative procedure should receive a just explanation in form of a timely notification proscribing at the same time the possible date of the expected decision. Moreover, the emphasis is also put on the decision-making process, execution of the administration and reaching administrative acts within a reasonable time frame. If a party fails to submit a request for administrative questioning within a proscribed deadline, the administrative act becomes final. The mentioned feature of the administrative act was stated by the former APA. ${ }^{64}$ The deadline is thus preclusive. Section 34 of the Preamble is also to be emphasized, since it enables the request for administrative questioning not to question the party's right to a judicial legal remedy. Due to specific features, it is a combination of an appeal and a complaint, considering the fact that the appeal is a devolutive legal remedy and is filed against the decision, while a complaint is a remonstrative legal remedy and is filed against the actions or proceedings. The Croatian administrative procedure acknowledges a complaint as a regular legal remedy, usually remonstrative, however in one of four cases it becomes a devolutive legal remedy (in administrative contracts). ${ }^{65}$

From the analysis of the Art. 20 of the EU APA, it is to be concluded that the provisions regarding legal remedies have been sub-normed. There are no explicit

\footnotetext{
$62 \quad$ See Table 1

63 See Art. 20 (4) of the EU APA

64 See Art. 11a, Official Gazette No. 53/91, 103/96

65 Art. 154 (2). Other cases of submitting objection: Art. 42(4), Art. 155(4), Art. 157(2)
} 
references of names of legal remedies as it is stated in Chapter 4, but only the mentioning of administrative questioning. The question which arises is what does the administrative questioning refer to in terms of content? Is the control of lawfulness and regularities of administrative acts implied? From the interpretations in Art. 20(3) of the EU APA one can conclude that it is a regular legal remedy, since it becomes final after a certain deadline. Another thing to point out is the fact that the official translation of the Regulation into Croatian language is quite uncoordinated with the Croatian administrative procedure terminology whereby using certain legal terms unfamiliar to the Croatian system.

Table 1 Comparison of the relevant procedural institutes: Croatian GAPA vs. Draft EU APA

\begin{tabular}{|l|l|l|}
\hline Institute & Croatian GAPA & Draft EU APA \\
\hline $\begin{array}{l}\text { Scope of the } \\
\text { law }\end{array}$ & $\begin{array}{l}\text {-general and special administrative } \\
\text { procedures } \\
\text {-administrative contracts, action of } \\
\text { public law authorities and public } \\
\text { services providers }\end{array}$ & $\begin{array}{l}\text {-administrative activities of the } \\
\text { Union's administration (Art. 1(1)) } \\
\text {-shall not apply to the administration } \\
\text { of the Member States (Art. 2(3)) }\end{array}$ \\
\hline $\begin{array}{l}\text { Fundamental } \\
\text { principles }\end{array}$ & $\begin{array}{l}\text {-10principles (Art. 5-14) } \\
\text {-partially applied European prin- } \\
\text { ciples (compound of tradition and } \\
\text { effect of process of Europeanization } \\
\text { and the reform of AP and PA) } \\
\text {-principle of proportionality, prin- } \\
\text { ciple of access to data and data pro- } \\
\text { tection }\end{array}$ & $\begin{array}{l}\text {-5rocedural rights (Art. 8) } \\
\text {-emphasized right to good adminis- } \\
\text { tration } \\
\text { - rule of law, right to be treated im- } \\
\text { partially, transparency and adminis- } \\
\text { trative efficiency, legal certainty, right } \\
\text { to be heard (preamble) }\end{array}$ \\
\hline $\begin{array}{l}\text { Deadline } \\
\text { for decision- } \\
\text { making }\end{array}$ & $\begin{array}{l}\text {-1st instance decision-without delay } \\
\text { and no later than within 30 days } \\
\text {-2nd instance decision-render the } \\
\text { decision and deliver it to the party } \\
\text { within 60 days } \\
\text { - in case of administrative silence } \\
\text { fiction of negative act (exceptionally } \\
\text { positive (Art. 102) and special laws) }\end{array}$ & $\begin{array}{l}\text {-3 months (Art. 17(1, 3)) } \\
\text {-reasonable time-limit and without } \\
\text { undue delay (Art. 17) }\end{array}$ \\
\hline $\begin{array}{l}\text { Legal remedies } \\
\text {-two regular legal remedies: appeal } \\
\text { and objection; } \\
\text {-three extraordinary legal remedies: } \\
\text { the reopening of proceedings, pro- } \\
\text { nouncing decisions null and void, } \\
\text { annulment and repeal of decisions }\end{array}$ & $\begin{array}{l}\text {-administrative review (Art. 20) } \\
\text {-rectification and withdrawal of acts } \\
\text { (which adversely affect a party (Art. } \\
\text { 23) and which are beneficial to a } \\
\text { party (Art. 24)) }\end{array}$ \\
\hline
\end{tabular}

Source: authors' work 


\subsection{Slovenian vs. Draft EU APA}

Slovenia has been a full member of the EU since 2004, which implies the direct application of a considerable amount of EU law. However, as far as procedural law is concerned, Member States are in principle autonomous insofar as they ensure respect for the principles of equivalence, efficiency, and good administration. This stems in particular from the case law of the European Court of Justice dealing with various procedural institutions, such as presenting evidence in proceedings, use of language, legal remedies and time limits, interference with final decisions, etc. (see, for example, Kühne \& Heitz,Tillack, Pelati, GrauelRüffer, H. N.). These cases serve as an important starting point for the basic solutions of the EU APA, or the two European Parliament resolutions of 2013 and 2016 and the draft EU Regulation itself. The latter has been publicly debated for many years for various professional (e.g. unclear relation between sectoral EU law and the EU Regulation, and a presumably overly academic approach to drafting provisions) and even more political reasons, such as the blockade by the Commission and other EU bodies whose powers the EU Regulation will restrict. Nevertheless, the EU Regulation is indeed important because it offers a set of good practices and a balanced codification that should give more weight to important principles and rules.

Below (Table 2) is a comparison between the Slovenian GAPA as a national traditional law, and the modern European codification. Concerning individual institutions, particularly the analysis regarding the possibilities of interfering with a decision through legal remedies, we can establish that in modern codifications, are less in number because of greater legal certainty and trust in the authorities.

Table 2 Comparison of the Slovenian GAPA and the draft EU APA on legal remedies

\begin{tabular}{|l|l|l|}
\hline Institutions & Slovenian GAPA & Draft EU APA \\
\hline $\begin{array}{l}\text { Scope of the } \\
\text { law }\end{array}$ & $\begin{array}{l}\text { Single-case administrative decision- } \\
\text { making\& real and other acts via } m u- \\
\text { tatis mutandis use of GAPA }\end{array}$ & $\begin{array}{l}\text { For EU bodies and individual ad- } \\
\text { ministrative matters only, prevalence } \\
\text { of general principles of EU law and } \\
\text { spill-over effect }\end{array}$ \\
\hline $\begin{array}{l}\text { Fundamental } \\
\text { principles }\end{array}$ & $\begin{array}{l}\text { Nine principles: legality, protec- } \\
\text { tion of their rights of parties and } \\
\text { protection of public benefits and } \\
\text { independence in deciding, Art. 6, 7, } \\
\text { 12; substantive truth with obligation } \\
\text { to tell truth and free assessment of } \\
\text { evidence, Art. 8, 10, 11; right to be } \\
\text { heard, Art. 9; appeal, Art. 13; econo- } \\
\text { my and timeliness, Art. 14 }\end{array}$ & As above (see Table 1) \\
\hline
\end{tabular}




\begin{tabular}{|l|l|l|}
\hline Time limits & $\begin{array}{l}\text { Two months, one month in short- } \\
\text { ened proceedings; in case of admin- } \\
\text { istrative silence fiction of negative act } \\
\text { and devolution }\end{array}$ & $\begin{array}{l}\text { Three months and potential exten- } \\
\text { sion, afterwards negative fictions act; } \\
\text { yet mostly about reasonable rather } \\
\text { than prescribed deadlines }\end{array}$ \\
\hline Legal remedies & $\begin{array}{l}\text { Rather many, appeal as precondition } \\
\text { for judicial review, and five more } \\
\text { extraordinary remedies, partially } \\
\text { duplicated reasons }\end{array}$ & $\begin{array}{l}\text { 2x } 2 \text { structure of actions that are } \\
\text { beneficial to or adversely affect, also } \\
\text { retroactively, the party (Art. 23 and } \\
24)\end{array}$ \\
\hline
\end{tabular}

Source: authors' work

\subsection{Summary of analysis and proposals on improving national GAPAs vs. EU law}

We can confirm that the benefits of a general codification of administrative procedure are clear. However, a strategic framework as a driving force of administrative development it only makes sense insofar as it contributes to ensuring international and constitutional principles of good administration, has an integrative and anti-fragmentary role by connecting different administrative areas and authorities at various levels of governance.

On the other hand, there seems to be more than enough arguments for a systematic revision of the Croatian and Slovenian GAPAs in terms of good administration as a constant weighing between protected interests. This means that it would be necessary to provide an entirely new codification of the general administrative procedure. In terms of content, new law should capture the majority of the spirit of the current GAPA, but would expose important principles such as effective legal remedy, distinguishing these provisions from others of minor weight. ${ }^{66}$ The latter would be either deleted or moved to implementing or organisational rules. The regulatory framework alone cannot suffice, even if highly detailed, as it always requires administrative and judicial review and academic explanations, which is another argument for a looser and more value-based codification. Furthermore, the protected interests should be constantly weighed to ensure a more efficient process.

Our analysis shows that a more consistent and not only declaratory respect is needed for the common values and principles of the EU, for a modern public administration and administrative law, and for the consequent development of the European Administrative Space - even at the national level, namely in (especially new) EU Member States. Therefore, administrative procedure should not consti-

${ }_{66}$ See more about this in Kovač 2019, op. cit., note 4. Cf. Koprić, et al. (2016), for the Western Balkans countries 
tute a tool for the authorities to ensure the dominance of the governing forces; authority should restrict itself by introducing into the administrative procedure the participation of the parties and ensuring an optimal enforcement of their rights and interests.

As regards legal remedies in particular, the EU trend is to have less of them or limited interventions are in place in order to guarantee legal certainty. Hereby, Slovenian and Croatian GAPAs still do not follow this main guideline, which is evident through (too) rather numerous legal remedies codified. And even more importantly, legal protection in administrative procedure and before the (administrative and constitutional) courts should be integrated into a coherent whole, so that one procedure is not just the other procedure's maid, but each has its own ratio and complements the other in the relation with the parties. Consequently, national GAPAs as Croatian and Slovenian could be improved to follow draft EU APA especially in two directions. Firstly, remedies shall not be defined by type of interest, but based on a trade-off between the degree of unlawfulness and favourable/aggravating consequences for the parties. Secondly, there is a need to connect and co-shape GAPAs and ADAs.

Regarding our initial research questions, we can establish that Croatian and Slovenian GAPAs share more similarities than differences despite the fact that Croatian law is ten years younger than Slovenian and has already taken into account some of the modern European trends. Very similar is also the relation between the GAPA and sectoral laws. Therefore, critical analysis as a result of comparison between national laws and Draft EU APA stands for both respective acts. In terms of good administration, provisions of Croatian as well as Slovenian GAPAs, could and should be consequently redefined to achieve more efficient yet democratic authority and administrative relations in the society. This will outline the advantages and disadvantages of the EU APA Proposal and suggest possible improvements in the analysed countries.

\section{CONCLUSION}

Although no uniformity of "procedural philosophy" has emerged, and the legal systems of European states and EU law differ in their assessment of the importance of procedural law, an idea is emerging that forms the basis for the creation of a common European procedural law. The authors point out that the administrative procedure requires joint regulation within the European administration, as well as the allocation of tasks in executive integration. Although such European administrative procedural act would not be directly applicable to national administrations (since most states have their own APAs), its effect would be clearly 
visible in every area of activity governed by EU (administrative procedural) law. However, it should be borne in mind that it's difficult to assume that the same or similar principles of administrative actions will exist in any national public administration, although this is sought. It is interesting to emphasize the importance of introducing the right to good administration, which sought to introduce minimum standards focused on the quality of administrations, while providing an information catalogue and a source of special rights for citizens. There is debate and interpretation about the guaranteed right to good administration, is it fundamental human right, principle or standard?

Although the European administration has grown significantly over the last few decades, the EU does not have a comprehensive law regulating citizens' procedural rights over European administrative procedure. We believe that the standardization contributes, particularly in the sectoral areas, to rationalization and simplification of procedures. EU legislation should ensure the adoption of regulation relating to the codification of administrative procedure by the Union's administration. Regarding a (mandatory) appeal should not be understood in a narrow sense and intended only to prevent the courts from having an excessive workload. The appeal - as in the case of Croatia and Slovenia following the Austrian model - should serve as a procedural precondition for court reviews or as an alternative together with mediation and other procedures for adjudicating and resolving a dispute between the parties to the case. Merely old patterns of administrative conduct, considering the radical social changes, no longer suffice. Therefore, the guiding principle of the two crucial legal sources of protection and promotion of fundamental rights and freedoms (European Convention and Charter of Fundamental Rights of the European Union) should not be forgotten, and ideas about the need to strengthen that protection by making those rights more visible.

\section{REFERENCES}

\section{BOOKS AND ARTICLES}

1. Auby, J.-B. (ed.), Codification of Administrative Procedure, Bruylant, Brussels, 2014

2. Avbelj, M. (ed.),Komentar Ustave Republike Slovenije [Commentary to the Constitution of the Republic of Slovenia], New University, NovaGorica, 2019

3. Bodoriga-Vukobrat, N.; Barić, S., Povelja temeljnih ljudskih prava Europske unije s komentarom, Organizator, Zagreb, 2002

4. Borchardt, K.-D., The ABC of European Union Law, Publications Office of the European Union, Luxembourg, 2010

5. Ćapeta, T.; Rodin, S., Osnove prava Europske unije na temelju Lisabonskog ugovora, Narodne novine, Zagreb, 2011 
6. Dragos, C.D., Administrative Appeal, in: Farazmand, A. (eds.) Global Encyclopaedia of Public Administration, Public Policy and Governance, Springer, Chma, 2016, pp. 1-7

7. Dragos, C.D.; Neamtu, B. (eds.), Alternative Dispute Resolution in European Administrative Law, Springer, Heidelberg New York, Dordrecht, London, 2014

8. Đanić, A.; Lachner, V., Utjecaj pojave globaliziranog upravnog prava na nacionalne upravne sustave s naglaskom na hrvatsko upravno postupovno pravo, in: Belaj, V. (ur.), Conference proceedings 2nd international conference Public administration development, Vukovar, Croatia, 11-12 May, 2012, pp. 163-179.

9. Đanić Čeko, A., Žalba u upravnom sporu u hrvatskom i poredbenom pravu, Pravni fakultet Sveučilišta u Zagrebu, Zagreb, 2016, doctoral thesis

10. Đanić Čeko, A., Specifičnost i uloge Visokog upravnog suda Republike Hrvatske u jednostupanjskom upravnom sporu na osnovi posebnih zakona (lex specialis), Harmonius Journal of Legal and Social Studies in Southand East Europe, vol. VII,2018, pp. 17-45

11. Đerđa, D., Upravni postupci u europskom pravu, Hrvatska pravna revija, vol. IX, no. 4, 2009, pp. $52-62$

12. Đerđa, D., Reforma sustava pravnih lijekova prema novom Zakonu o općem upravnom postupku, in: Koprić, I., Đulabić, V. (ur.), Modernizacija općeg upravnog postupka I javne uprave u Hrvatskoj, Suvremena javna uprava, Zagreb, 2009, pp. 155-179

13. Đerda, D., Towards the Codification of the EU Administrative Procedural Law, in: Koevski, G (eds.) EU Administrative Law and its Impact on the Process of PAR and Integration into the EAS of South East European Countries, Skopje: Centre for SEELS, 2014, pp. 79-83

14. Đerđa, D.; Jerčinović, A., Upravni postupak u pravu Europske unije: kodifikacijsk iizazov, Zbornik radova Pravnog fakulteta u Splitu, vol. 57, no. 1, 2020, pp. 85-126

15. Franchini, C., European Principles Governing National Administrative Proceedings, Law and Contemporary Problems, vol. 68, no. 1, 2004, pp. 183-196

16. Galetta, D.-U. et al., The General Principles of EU Administrative Procedural Law, European Parliament, Brussels, 2015

17. Gjidara, M.; BritvićVetma B., Francusko-hrvatski pojmovnik, Split/Paris, 2016

18. Klučka, J., The General Trends of EU Administrative Law, The International Lawyer, vol. 41, no. 4, 2007, pp. 1047-1054

19. Koprić, I.; Đulabić, V. (eds.), Modernizacija općeg upravnog postupka i javne uprave u Hrvatskoj [Modernisation of Administrative Procedure and Administration in Croatia], Suvremena javna uprava, Zagreb, 2009

20. Kovač, P., The requirements and limits of the codification of administrative procedures in Slovenia according to European trends, Review of Central and East European law, vol. 41, no. 3/4, 2016, pp. 427-461

21. Prechal, S.; Widdershoven, R.J. G.M.; Jans, J.H., Introduction, in: Prechal, S.; Widdershoven, R.J. G.M.; Jans, J.H., (eds.), Europeanization of Public Law (second edition), Europa Law Publishing, Groningen, 2015, pp. 3-36

22. Ruffert, M., Common Principles and National Traditions: Which Perspective for European Administrative Legal Scholarship?, in: Ruffert, M. (ed.), Administrative Law in Europe: Between 
Common Principles and National Traditions, Europa Law Publishing, Groningen, 2013, pp. 215-221

23. Rusch, W., Administrative Procedures in EU Member States, OECD/SIGMA, „Conference on Public Administration Reform and European Integration-Budva, Montenegro“, 2009, pp. $1-10$

24. Schmidt-Aßmann, E., Administrative Law in Europe: between Common Principles and National Traditions, in: Ruffert, M. (ed.), Administrative Law in Europe: Between Common Principles and National Traditions, Europa Law Publishing, Groningen, 2013, pp. 3-15

25. Schwarze, J., European Administrative Law, Sweet and Maxwell, Luxembourg, 1992

26. Schwarze, J., Judicial Review of European Administrative Procedure, Law and Contemporary Problems, vol. 68, no. 1, 2004,pp. 85-105

27. Stelkens, U., Administrative Appeals in Germany, in: Dragos. D. C.; Neamtu, B. (eds.), Alternative Dispute Resolution in European Administrative Law, Springer, 2014, pp. 3-55

28. Turčić, Z., Komentar Zakona o općem upravnom postupku s prilozima, sudskom praksom abecednim kazalom pojmova, treće i dopunjeno izdanje, Organizator, Zagreb, 2012

29. Verhoeven, M., The Costanzo Obligation, Intersentia, Ius Commune Europaeum, Book93, 2011

30. Widdershoven, R., European Administrative Law, in: Seerden, J. G. H. R. (ed.), Administrative Law of the EU, its Member States and the United States, A Comparative Analysis (third edition), Intersentia, Ius Commune Europaeum, Book 109, 2012, pp. 245-319

\section{LIST OF NATIONAL REGULATIONS AND ACTS}

\section{Croatia}

1. Constitution of the Republic of Croatia, Consolidated text, Official Gazette No. 56/90, $135 / 97,113 / 00,28 / 01,76 / 10,5 / 14$

2. Administrative Dispute Act, Official Gazette No. 20/10, 143/12, 152/14, 94/16, 29/17

3. Competition Act, Official Gazette No. 79/09, 80/13

4. Croatian Services Act, Official Gazette No. 80/11

5. General Administrative Procedure Act, Official Gazette No. 53/91, 103/96

6. General Administrative Procedure Act, Official Gazette No. 47/09

\section{Slovenia}

1. Constitution of the Republic of Slovenia (Ustava Republike Slovenije), Official Gazette of the Republic of Slovenia, No. 33/01-I and amendments

2. General Administrative Procedure Act (Zakon o splošnem upravnem postopku, ZUP), Official Gazette of the Republic of Slovenia, No. 80/99 and amendments

3. Administrative Dispute Act (Zakon o upravnem sporu, ZUS-1), Official Gazette of the Republic of Slovenia, No. 105/06 and amendments 


\section{EU (DRAFT) LAW}

1. Charter of Fundamental Rights of the European Union (2016/C 202/02), Official Journal of the European Union, C 202/389, 2016

2. Directive 2006/123/EC of the European Parliament and of the Council of 12 December 2006 on services in the internal market, OJ L 376, 27.12.2006

3. European Parliament resolution of 15 January 2013 with recommendations to the Commission on a Law of Administrative Procedure of the European Union (2012/2024(INL))

4. European Parliament resolution of 9 June 2016 for an open, efficient and independent European Union administration (2016/2610(RSP)),Proposal for a Regulation of the European Parliament and of the Council for an open, efficient and independent European Union administration

\section{COURT OF JUSTICE OF THE EUROPEAN UNION}

1. Case C-453/00 Kühne \& Heitz NV v. ProduktschapvoorPluimvee en Eieren, [2004] ECLI:EU:C:2004:17

2. Case C-234/04 Rosmarie Kapferer v. Schlank \& Schick GmbH [2006] ECLI:EU:C:2006:178

3. Case C-507/08 EC v. Slovakia [2012] ECLI:EU:C:2010:802

4. Case C-603/10 Pelati d.o.o. v. Slovenia [2012] ECLI:EU:C:2012:639

5. Case C-90/18 Hrvatska banka za obnovu i razvitak (HBOR) v Povjerenik za informiranje Republike Hrvatske [2018] ECLI:EU:C:2018:685

6. Case C3/16 Aquino v. BelgischeStaat [2017] ECLI:EU:C:2017:209

7. CaseC161/15BensadaBenallal v Étatbelge [2016] EU:C:2016:175

8. CaseC74/14EturasandOthers $v$ Lietuvos Respublikos konkurencijo staryba [2016] EU:C:2016:42

\section{WEBSITE REFERENCES}

1. [https://pretinac.gov.hr/KorisnickiPretinac/eGradani.html], accessed 28. March 2020

2. Barkhuysen, T.; Ouden den, W.; Schuurman, Y.E., The Law on Administrative Procedures in the Netherlands, NALL 2012, april-juni, pp. 1-26.,[https://openaccess.leidenuniv.nl/bitstream/handle/1887/19406/NALL-D-1200004.Law\%20on\%20admp.pdf?sequence=2], accessed 22. March 2020

3. Cărăuşan M., Towards an Administrative Procedure of the European Union: Issues and Prospects, Acta Universitatis Danubius, vol. 8, no. 2, 2016, pp. 79-90,[https://www.researchgate. net/publication/331089750_Towards_an_Administrative_Procedure_of_the_European_ Union_Issues_and_Prospects], accessed 17. March 2020

4. Đanić Čeko, A., Has the Implementation of the One-Stop-Shop (Point of Single Contact) enabled simplification of the Croatian Administrative Procedure to increase the efficiency of Public Administration?, in:Cingula, M.; Rhein, D.; Machrafi, M. (eds.), Book of Proceedings,31st International Scientific Conference on Economic and Social Development - "Legal Challenges of Modern World”, Split, Croatia, 7-8 June 2018, pp. 580-588, [http://www. esd-conference.com/past-conferences], accessed 24. March 2020 
5. Đanić Čeko, A.; Petrašević, T., Procedural Rights of the Parties in Croatian and European Administrative Procedure-lack of one common Administrative Procedure?, Public Administration in a Democratic Society: Thirty Years of Democratic Transition in Europe, International Conference, Dubrovnik, Croatia, 3-6 October 2019, [https://iju.hr/ipsa/2019/papers/ ip19p27.pdf], accessed 20. March 2020

6. Galetta, D.-U. et al., The General Principles of EU Administrative Procedural Law, Brussels, European Parliament, 2015, pp. 1-26,[https:/www.europarl.europa.eu/RegData/etudes/ IDAN/2015/519224/IPOL_IDA\%282015\%29519224_EN.pdf], accessed 25. March 2020

7. Hofmann, H.C.H.; Schneider, J.-P., Ziller, J. (eds.), The ReNEUAL Model Rules, 2014, [http://www.reneual.eu/images/Home/ReNEUAL-Model_Rules-Compilation_BooksI_ VI_2014-09-03.pdf], accessed 25. March 2020

8. Koprić, I. et al., Legal Remedies in Administrative Procedures in Western Balkans, ReSPA, Danilovgrad, 2016, [http://www.respaweb.eu/11/library\#respa-publications] accessed 26. March 2020

9. Koprić, I., Administrative Procedures on the Territory of Former Yugoslavia, Brussels, OECD, SIGMA, 2005, pp. 1-8, [http://www.sigmaweb.org/publications/36366473.pdf], accessed 25. March 2020

10. Koprić, I.; Kovač, P. (eds.), European Administrative Space: Spreading Standards, Building Capacities, Bratislava, NISPAcee, 2017,[http://www.nispa.org/files/publications/proceedings/NISPAcee-Proceedings-2016-Zagreb.pdf], accessed 25. March 2020

11. Kovač, P., Principles of administrative procedure in selected CEE countries: between national legacies and European trends, Public Administration in a Democratic Society: Thirty Years of Democratic Transition in Europe, International Conference, Dubrovnik, Croatia, 3-6 October 2019. [https://iju.hr/ipsa/2019/papers/ip19p2.pdf], accessed 25. March 2020

12. Livioara Goga, G., The Obligation of the National Administrative Organs to Reexamine their own Decisions in the Context of the Recent Jurisprudence of the Court of Justice of the European Union, Acta Universitatis DanubiusJuridica, vol. 16, no. 3, 2010, pp. 162-169, [http://journals.univ-danubius.ro/index.php/juridica/article/view/677/634], accessed 15. March 2020

13. Siuciński, R., Convergence of Law-Examples from European Administrative Procedure, Vilnius, 2013, pp. 303-308,[http://www.tf.vu.lt/dokumentai/naujienos/Renginiai/tarptautine_studentu_konferencija_2013.pdf], accessed 17. March 2020

14. Strategija razvoja javne uprave za razdoblje od 2015. do 2020. godine, [https://www.sabor. $\mathrm{hr} / \mathrm{hr} /$ prijedlog-strategije-razvoja-javne-uprave-za-razdoblje-od-2015-do-2020-godine], accessed 26. March 2020

15. Venice Commission (Council of Europe), Stocktaking on the Notion of Good Governance and Good Administration. Study 470/2008, CDL-AD (2001)009, 2011, pp. 1-30, [https:// www.venice.coe.int/webforms/documents/?pdf=CDL-AD(2011)009-e], accessed 25. March 2020 